\title{
NOTES TO THE AUSTRALIAN SPONGES RECENTLY DESCRIBED BY CARTER. (1)
}

\author{
By R. von Lendenfeld. Ph.D.
}

As I am just now engaged in writing a Monograph of the Australian Sponges, I was particularly glad to receive the publications on the subject by Carter through the courtesy of the author.

There are in the part concerning the Ceraospongiæ and Myxospongia, no figures and the diagnoses are so short that it is, in a great number of cases, impossible for me to identify them with the specimens in my collection or to ascertain those characteristics which I consider as most important.

There are some, however, which in consequence of some accessory peculiarity or other I have been able to recognize. My collection of several thousand specimens of Australian Sponges is by far the finest as yet brought together from this locality, and I think that not only Carter but also all other scientists, who are working the Sponges will be interested in the result of a comparison between Carter's diagnosis and the specimens in my collection.

Halisarca australiensis (2) is not a Sponge at all, but the crusts described by Carter under the above name are the ova of Boltenias, surrounded by their Follicula. I myself believed that the slimy coatings in question were perhaps Sponges, and I examined them accordingly. The result of this examination are laid down in a paper published by me last year.

(1) H. J. Carter. Description of Sponges from the neighbourhood of Port Phillip Heads, South Australia. Annals and Magazine of Natural History, Ser. 5, Vol. XV., p. 196.

(2) H. J. Carter. L.c., p. 197.

(3) R. von Lendenfeld. On the slimy coatings of certain Boltenias in Port Jackson. Proceedings of the Linnean Society of N.S.W., Vol. IX., p. 495. 
The Boltenia is probably Boltenia australis. The name Boitenia australiensis given by Carter ( 1 ) is not warranted.

Chondrilla nucula O.S, is mentioned as occurring in Port Phillip. (2) I have not found any specimens of this Sponge in any part of the Australian coast. I have, however, described a species of Chondrilla as C. secunda, n.s., from Port Phillip, in a paper read some time ago before the Linnean Society of N.S.W. (3) This species is somewhat different from C. nucula O.S., in the shape of its spicules, and particularly the configuration of the canal-system, but which outwardly appears very similar to the Adriatic species, of which I brought a specimen with me. I think it very probable that Carter's specimen is to be referred to my Chondrilla secunda, a Sponge very abundant in Port Phillip.

Luffaria digitata (4) is very meagerly described, but I think it highly probable that it is identical with a Sponge described eighteen years ago by Selenka (5) as Spongelia cactos, which has also been investigated by F. E. Schulze (6) and myself (7).

Carter has apparently not seen my paper on Sponges of Port Phillip, otherwise I think that my description of this Sponge would have been sufficient for identification. I have named it Dendrilla rosea, which name having priority, ought to replace the name Luffaria digitata given by Carter.

(1) H.J. Carter. Description of Sponges from the neighbourhood of Port Phillip Heads, South Australia. Annals and Magazine of Natural History, Ser. 5, Vol. XV., p. 197.

(2) H. J. Carter. L.c., p. 200.

(3) R. von Lendenfeld. A Monograph of the Australian Sponges. Abstracts of Proceedings of the Linnean Society for January, 1885.

(4) H. J. Carter. L.c., p. 201.

(5) E. Selenka. Ueber neue Schwämme aus der Südsee. Zeitschrift für wissenschaftliche Zoologie. Band 17, Seite 566, Tafel 35, fig. 5.

(6) F. E. Schulze. Untersuchungen über den Bau und die Entwickelung der Spongien. Die Familie der Aplysinidæ. Zeitschrift für wissenschaftliche Zoologie. Band 30, Seite 379.

(7). $R$. von Lendenfeld. Ueber Cœlenteraten der Südsee II. Neue Aplysinidæ. Zeitschrift für wissenschaftliche Zoologie. Band 38, Seite $277 \mathrm{ff}$.

(8) H. J. Carter. L.c., p. 201. 
The most important feature of the Sponge is its peculiar subdermal cavity. Carter does not mention this, but as he does not say anything about the canal system at all, it is probable that he never examined any section-series.

Darwinella australiensis (1) is represented in my collection, but the canal system is not described by Carter, so that it is difficult to identify the species.

As Aplysina lævis (2) Carter, seven distinct species in my collection could be considered. These are very different from one another, but all coincide with Carter's diagnosis of the above species. They are forms which led to the Dysididæ of Marshall (3), of which Carter's Pseudoceratina durissima (4) may be a true representative.

The diagnosis given by Carter of Aplysina purpurea (5), led me to believe that it might be identical with a Sponge examined by me, and named Aplysilla violacea (6), but now it seems that this is not the case, as Carter considers the Australian specimen of that Sponge to be identical with his Pseudoceratina durissima (7.)

Carter's new genus Halapsamina(8), is identical with Marshall's genus Psammapemma (9), established five years ago, and the latter name must be accepted as it has priority.

(1) H. J. Carter. Description of Sponges from the neighbourhood of Port Phillip Heads, South Australia. Anmals and Magazine of Natural History, Ser. 5, Vol. XV., p. 203.

(2) H. J. Carter. L.c., p. 204.

(3) William Marshall. Ueber Dysididen und Phoriospongien. Zeitschrift für wissenschafsliche Zoologie. Band 35, Seite 92.

(4) H. J. Carter. L.c., p. 204,

(5) H. J. Carter. Contributions to our knowledge of the Spongida. Order II., Ceratina. Annals and Magazine of Natural History, Series 5, Vol. VIII, pp. 103-105.

(6) R. von Lendenfeld. L.c.. Seite $237 \mathrm{ff}$.

(7) H. J. Carter. Description of Sponges from the neighbourhood of Port Phillip Heads, South Australia. Annals and Magazine of Natural History, Series 5, Vol. XV., p. 205.

(8) H. J. Carter. L.c., p. 211.

(9) William Marshall. L.c., seite 113. 
The species described as $H$. crassa (1) and H. lævis (2) cannot be distinguished. I possess in my collection numerous transition forms between them, and all these ought to be combined under the name given to them previously by Marshall (3), viz., Psammapemma densum. I think that I shall be able to distinguish a few species as the canal system is not the same in all the specimens $\mathbf{I}$ have examined. It is however, connected with quite unusual difficulties to make good series of sections through these arenaceous Sponges.

Holopsamma laminæfavosa (4), may be identical with Marshall's genus Psammoclema (5.)

Both Holopsamma fuliginosa (6), and turba (7) are unrecognisable.

The establishment of a new genus Sarcocornea (8), for a dry Dysidea is not justified. In the diagnosis there is nothing by which the only species could be distinguished from Dysidea.

Dysidea fragilis Johnstone (9) and Dysidea Kirkii Bowerbank (10) are mentioned. I only possess the latter in my collection. Chaliniform species are very abundant and I possess long series of continuous transition-forms. I believe this shape to be caused by mimicry after the true Chalinidae, which in consequence of their axial spicules are not very digestible food.

I cannot say anything about the species described as Dysidea hirciniformis (11) and chaliniformis (12). The descriptions are so short that it is simply impossible to make any use of them.

(1) H. J. Carter. Descriptions of Sponges from the neighbourhood of Port Phillip Heads, South Australia. Annals and Magazine of Natural History, Ser. 5, Vol. XV., p. 211.

(2) H. J. Carter. L.c., p. 212.

(3) William Marshall. Ueber Dysididen und Phoriospongien. Zeitschrift für wissenchafsliche Zoologie. Band 35, Seite 113.

(4) H. J. Carter. L.c., p. 212.

(5) William Marshall. L.c., Seite 109.

(6) H. J. Carter. L.c, p. 213.

(7) H. J. Carter. L.c., p. 213.

(8) H. J. Carter. L.c., p. 214.

(9) H. J. Carter. L.c., p. 215.

(10) H. J. Carter. L.c., p. 216.

(11) H. J. Carter. L.c., p. 217.

(12) H. J. Carter. L.c., p. 217. 
I consider the genus Dysidea as characterised by the following points :-

(1). Transparent hyaline Mesoderm without foreign bodies in the ground substance. (1)

(2). The canal system and ciliated chambers of Spongelia as described by Schulze.

(3). Foreign bodies forming all the fibres.

It can of course not be decided by the description whether Carter's specimens belong to the genus Dysidea in this sense or not.

The sponge described by Carter as Spongelia stellidermata (2) is probably identical with some specimens in my collection which, however, do not belong to the genus Spongelia but to another Family (3), that of the Spongidæ. I have named this Sponge Cacospongia gracilis (4) but it may appear necessary to establish a new genus for it At all events it does not belong to the genus Spongelia Schulze, who was the first to establish a diagnosis on a rarely reliable and scientific basis (5).

Carteriospongia caliciformis (6) is described from a dry specimen so that no opinion can be hazarded at to its real position in the system.

(1) F. E. Schulze. Untersuchungen über den Bau und die Entwickelvung der Spongien. Die Gattung Spongelia Zeitschrift für wissenschaftliche Zoologie, Band 32, Seite $111 \mathrm{ff}$.

(2) H. J. Carter. Descriptions of Sponges from the neighbourhood of Port Phillip Heads, South Australia. Annals and Magazine of Natural History, Ser. 5, Vol. XV., p. 219.

(3) G. Vosmaer. Studies on Sponges I. Mittheilungen der Zoologischen Station in Neapel, Band IV., Seite 445. (Vosmaer's classification is identical with mine, which I arrived at independently, and which is therefore very likely to be correct.)

(4) In 1883, I identified the Sponges from several Museums, and I supplied several with names, the diagnoses of which remained in schedule. The Sponges referred to can be seen in the Museum of the South Australian Institute at Adelaide.

(5) F. E. Schulze. L.c.

(6) H.J. Carter. L.c., p. 221. 
As the configuration of the canal system is not described and the microscopic structure of the soft parts generally hardly referred to, and as these are considered all-important by me, it is only natural that I should not be able to utilize Carter's Essay. Just as it was necessary that $\mathrm{O}$. Schmidt compared Bowerband's species with his own I find it advantageous to review Carter's essay from my point of view, so that anyone may be enabled to make use of it. To those who hold the views of Poléjaeff, Vosmaer and myself, this review will be most welcome. As I am in possession of extensive collections and working the subject on the spot, I have thought myself in a position to write this review. 


\section{$2 \mathrm{BHL}$ Biodiversity Heritage Library}

Lendenfeld, R. von. 1885. "Notes to the Australian sponges recently described by Carter." Proceedings of the Linnean Society of New South Wales 10, 151-156. https://doi.org/10.5962/bhl.part.17909.

View This Item Online: https://www.biodiversitylibrary.org/item/30482

DOI: https://doi.org/10.5962/bhl.part.17909

Permalink: https://www.biodiversitylibrary.org/partpdf/17909

\section{Holding Institution}

MBLWHOI Library

\section{Sponsored by}

MBLWHOI Library

\section{Copyright \& Reuse}

Copyright Status: NOT_IN_COPYRIGHT

This document was created from content at the Biodiversity Heritage Library, the world's largest open access digital library for biodiversity literature and archives. Visit BHL at https://www.biodiversitylibrary.org. 